Scientific Journal of October 6 University

ISSN (Print): 2314-8640

ISSN (Electronic): 2356-8119

Published by October 6 University @ All Rights Reserved

Available online at: http:// sjou.journals.ekb.eg

Original Article
Citation: Mohamed Elsayed M. Attia, The international experiences for the tax systems reform. Sci. J. of Oct. 6 Univ. 3(2), 67-75

Copyright: (C) 2016 Mohamed Elsayed M. Attia. This is an open-access article distributed under the terms of the Creative Commons Attribution License, which permits unrestricted use, distribution, and reproduction in any medium, provided the original author and source are credited.

\title{
The international experiences for the tax systems reform
}

\author{
Mohamed Elsayed M. Attia \\ Manager of Tax Studies administration, Research Sector, Egyptian Tax Authority (ETA)
}

Received: 14-04-2016 Revised: 22-04-2016 / Accepted: 02-05-2016

\begin{abstract}
Taxes are the most important matter for any economy, they provide the sustainable funding needed for social programs and public investments to promote economic growth and build a prosperous society. But policy makers face difficult challenges in formulating good tax policies. They need to be guided by the principles of taxation in order to find the right balance between raising revenue and ensuring minimum efficiency and removing distortions in the economy, equitable distribution of tax burdens, and low administrative burden of tax compliance cost. Thereby, levying taxes is not an easy task, especially in the wake of Egyptian revolution, with the big financial deficits. So, government needs to benefit from the international experiences for tax reform, as we see in this study.
\end{abstract}

Key Words: Tax, reform, experiences, Challenges, efficiency, equity.

\section{Introduction}

Economists have for many years debated the principles which should underpin taxation going back to book of Adam Smith's Wealth of Nations which set out four "canons of taxation": equity; certainty; convenience and efficiency. These principles still remain valid, but more recent tax reforms particularly in the richer economies of the West have focused on ensuring that the tax system encourages, rather than discourages, productive wealth creation (Andrew , 2015).

One basic idea underlying justice in taxation is that taxpayer should be taxed in accordance with their "ability to pay". In this context an income tax comes closer to taxing people according to their ability to pay than perhaps any other tax, which is a principal reason why the individual income tax a mainstay in most tax system. Although widespread in use, the income tax has been debated on a number of fronts including: equity (vertical and horizontal), economic efficiency, and tax compliance cost (Roy, 1996).

However, there is broad agreement that the comprehensive Egyptian tax reform is essential to improve competitiveness and rebuild our nation's economic future. Government has developed a set of broad principles for tax reform that, if adopted, will make a significant contribution to maintaining Our tax revenues to improve sustained economic growth. The goal of tax reform should be to support jobs creation, economic growth and competitiveness [Advanced Medical Technology association report: without year].

These principles have taken special importance in the Egyptian tax system over the last years and not only for the success of tax policy but also for the reform success of government fiscal relations, domestic and international (Jorge et al., 2007)So, Questions arose about tax reform? The importance of this reform? Tax reform challenges? The most important international experience for tax reform? The most important lessons learned from these experiences? We will try to answer these questions in this study.

Objective of the study: This study aims to release the most important lessons learned from the international experience of tax reform.

Therefore, we can display this study in two sections as follow: (1) Challenges of the international tax reform. (2) Lessons from the international experiences for tax reform.

\section{Section one:}

\section{Challenges of the international Tax reform:}

The main purpose of taxation is to raise resources to finance government expenditure. We may see the problem of tax design as one of finding a way of raising these resources, which is administratively and politically feasible, and which promotes equity and efficiency as far as is possible. The problem of tax reform is to find an improvement, with respect 
to these criteria, of an existing system. Equity and efficiency, in much of the formal, normative part of the analysis, will be considered in terms of the well-being of households. These criteria and concerns may be common to governments in both developed and developing countries (Robin et al., 1993).

The latest results from the Paying Taxes study to the World Bank Group in report 2015, show many economies are continuing to make progress in tax reform. At the same time, around the world there is still a lot of scope for new or further actions to streamline and simplify tax systems, to reduce economic distortions and reduce the burden imposed on business. Tax reform is therefore set to remain an important topic for governments around the world for many years to come. The Paying Taxes study focuses mainly on the administrative efficiency of the tax system and the overall burden imposed on business, but there is a broader economic dimension to tax reform too contain some challenges, which it need to treat in order to achieve sufficient tax reform.

We see these challenges being applied in a number of economies around the world at present. For example, the UK has implemented major reforms of its taxation of companies aimed at bringing down the headline rate of corporation tax on profits from $(28 \%)$ to $(20 \%)$ by $2015 / 16$. In his 2013 Budget, the Chancellor of the Exchequer George Osborne argued that this would give the UK the most competitive corporate tax regime in the G20 with a significantly lower tax rate on profits than the US, Japan, Germany and France.

In Japan, the government under Shinzo Abe is undertaking a number of reforms aimed at improving the growth performance of its economy. These include a gradual rise in the Japanese VAT rate from $(5 \%)$ to $(10 \%)$, the first stage of which has already been implemented. Japanese tax reform also includes a reduction in the corporate income tax rate from $(35 \%)$ to $(30 \%)$.

But in these attempts to make tax reforms, we also see some of the problems and challenges, which governments regularly encounter as they seek to restructure and improve their tax systems, and make them more conducive to economic growth and employment.

There are four big challenges in any process of tax reform, and successfully navigating these potential difficulties is the key to successful implementation of tax reform policies.

The first major issue is that changes to the structure of the tax system create winners and losers. Individuals or companies which benefit from lower tax rates may not be the same as those adversely affected by restricting tax exemptions and allowances. Rises in VAT and other spending taxes which we have seen in many European countries and we are now seeing in Japan squeeze consumers and governments come under pressure to offset this impact, particularly on poorer households. This problem can be addressed by finding ways of compensating the losers but that in turn may mean there is a net fiscal cost to tax reform.

In the short-term at least, the government can find it gets less revenue after the reform than it did before particularly if the reform involves cutting tax rates. The longer term benefits that tax reform can bring to growth, and public finances take much longer to feed through. This can be problematic, when as in the case of the UK and Japan and many other governments, at present the size of the government deficit and the rising burden of public debt is also a key issue for national economic policy.

The second major issue is that it is easy to put off tax reform. There is no ideal time to restructure the tax system, and short-term political pressures can get in the way. The best environment to restructure the tax system is where there is a strong government, with a substantial electoral majority, and hence a mandate for change. But when governments are feeling less confident, it is much less easy to make change. The shift to taxing consumer spending more heavily which is now underway in Japan has been on the agenda since the 1990s. It is only under the Abe administration that it is being implemented, and even now there are concerns that the Japanese economy may not be able to withstand the impact of rising taxes in the short-term.

Third, from the perspective of economic growth and competitiveness, it is the impact of the tax system as a whole which is important not individual taxes. Tax reforms should be designed and implemented with a focus on their broader economic impact, not just on a specific area of the tax system. While the UK government is keen to highlight its success in reducing corporate profit taxes, other tax changes have had less positive impacts on the overall climate for growth and employment.

The main payroll tax has risen and the increasing burden of other business taxes has been an issue of concern including business property taxes (Uniform Business Rates) and taxes on business inputs such as fuel. The rise in the top rate of income tax to (50\%) also had an adverse impact on perceptions of the competitiveness of the UK as a business location and has since been partially reversed with the cut in the highest income tax rate to $(45 \%)$. 
Finally, fighting political and economic pressures to increase the complexity of the tax system is an ongoing battle. Specific tax reliefs and allowances are much easier to introduce than they are to abolish. Special interest and lobby groups are always arguing for tax changes which they see as helpful, and some of these may be genuinely positive for short-term economic prospects. A government may see political advantage in granting these requests. But there are many fewer voices in the public debate for a fundamental overhaul of the tax system which generates long-term economic benefits. Over time, the result is a more complex and less coherent tax system which can only be improved by visionary and principled tax reforms. The major advanced economies in Europe, North America and in the Asia Pacific region have battled with these issues for many years. But the need for more radical tax reform has become more pressing since the financial crisis. The major western economies and Japan are stuck in a "new normal" of slow growth which risks continuing into the second half of this decade. One of the major levers available to governments to improve underlying growth prospects is tax reform. In the 1980s, tax reform was an important ingredient revitalizing growth in the UK, US and other western economies and helping them escape from the doldrums of the 1970s.

So it is time for a new era of tax reform across key regions of the world economy. But the success of governments in carrying this through will depend on their ability to address the four key challenges highlighted earlier: supporting losers as well as rewarding winners; avoiding the temptation to put off change; looking at the tax system as a whole; and fighting the temptation to make the tax system more complex for economic and political reasons (Andrew, 2015)

The World Bank has identified the following as among the most pressing challenges that Egypt faces, in achieving sustainable development: High unemployment and increasing poverty. Despite increased economic growth, the number of those living below the poverty line is increasing, and few Egyptians have benefited from the economic reform agenda. The government recognizes this challenge, and plans to mitigate it by sustaining high economic growth. However, has not yet translated into clear and effective policies to tackle rising inequality or ensure more equitable distribution of the benefits of economic growth (Bank Information Center (BIC), 2007). Consequently, Egypt need tax reform an urgent basis to meet the requirements of sustainable development.

There are different views about what tax reform should accomplish. Unfortunately, all of them are to some extend correct. Some would say that the unfairness of the tax system is a root problem, i.e. some taxpayers pay full taxes while others escape the tax net, either legally or through evasion. Yet others would point to the need for tax increases to cover the cost of servicing the high level of debt that has be taken on. It is incumbent on government to decide which objective is most important (Roy et al., 2007).

So, the question arises, what makes a good Egyptian tax system? Accordance to the Doing Business reports, we offer below some suggestions for what might be seen as a road map of a good tax system, which is a summary of the above. As a starting point, we have listed (20) proposal which it consider the suggestions of a good tax system in Egypt, but perhaps these proposals will need further development over time. We can show this proposal through table (1) as we will see.

\section{Section two: \\ Lessons from international experiences for tax reform:}

In the last few years the development community at large has at last begun to take seriously some of the problems arising from the weakness in many countries of the critical link between taxation and development. In a recent useful survey of the aid literature, (2013) identifies some of the critical issues many developing countries face with respect to strengthening the link between tax and development that have been highlighted in the recent development literature:

1- The need to increase revenues to finance major social and infrastructure needs;

2- The need to design taxes to favor efficiency, growth and equity;

3 - The need to reduce tax exemptions to increase the tax base and reduce evasion;

4- The need to reduce taxes on the poorest and to increase taxes on the richest;

5- The need to deal more adequately with profitshifting by multinational companies;

6- The need to design and implement taxes with careful attention to the implications for improving the quality of governance (Jorge and Richard, 2015).

Thereby, it are still major difficulties in ensuring that effective and equitable taxation systems are fully functioning in developing countries. Some progress has been made but in terms of tax collection levels progress is far from what was hoped the 'tax consensus' would deliver (Chaire, 2014).

However, the question arises, what are extracting lessons from the international experience with tax reform?

Governments need to revenues to provide public services to society. To finance these services, the 
vast majority of governments must levy taxes. The challenge for governments is to find a way to do so that ensures public revenues while encouraging compliance. So, tax reforms are usually controversial, attracting intense political debate. The choice is often perceived as being between lower taxes with more votes but potentially less government revenue, and higher rates with discontented voters but potentially smaller fiscal deficits. In reality there is often no tradeoff between revenues and votes.

In the past (5) years, Doing Business has recorded (171) reforms in paying taxes in (105) economies around the world. Reforms aimed at making tax compliance easier and the tax burden lighter for small and medium-size businesses. Reformers in economies as diverse as Egypt, Mauritius and Turkey have underscored the importance of tax reform in enhancing economic growth, increasing competitiveness, combating unemployment and achieving good governance. Since 2005, (90) reforms in (65) economies have pointed to the (4) most successful reforms: Making tax Systems Electronic, Combine taxes, Simplify tax administration, Reduce tax rates and broaden the base, (World Bank, Doing Business Report, 2010) as follow:

First lesson: Making Tax Systems Electronic: Many economies are eager to make use of technology to ease the paying of taxes, if properly implemented, and adopted by businesses. Electronic tax systems speed up processing, improve data collection and reduce error rates. Electronic payment can be implemented in several ways, including through the internet. Another way is through automatic bank transfer, popular across all regions and income levels, mainly because taxpayers perceive it as less prone to security risks. In many developing economies access to the internet remains an obstacle. But adoption of new systems can be slow for reasons that cut across economies at all levels of development. Most critically, taxpayers need to trust the payment system. This requires high-quality security systems to protect data. Also required are laws addressing data protection and privacy concerns and allowing electronic signatures.

In the United States in 2009, the error rate was less than $(1 \%)$ for electronically prepared and filed returns but about $(20 \%)$ for paper returns. To encourage use of new technology, Peru and South Africa provide free software that makes the filing process automatic. France eased access while maintaining security by scrapping its electronic verification software. Taxpayers can now verify their identity with the numbers on their annual declaration and their notice of assessment. In Chile taxpayers can use their universal identification number and a password. Sharing gains from administrative efficiency is a way to encourage taxpayers to use the system. A quarter of the world's countries have electronic filing and payment of business taxes. That means no need for paper documents and no need for personal interaction with tax officers. A third of the world's countries now use electronic payment such as bank transfer and half use payment by check. In Mozambique the tax authority favors check payments by clearing them faster than bank transfers. But this choice has not been incident free: some checks were deposited in accounts belonging to tax officers.

Almost (70) of the (183) economies covered by Doing Business offer electronic tax filing and payment options to businesses. In (56) economies the electronic systems are used by a significant share of businesses. Not surprisingly, among OECD high-income economies all, but one permit firms to file and pay taxes electronically. But the trend is also picking up among developing economies. In the past (5) years (31) economics have introduced fairly comprehensive electronic systems. Among OECD high-income economies, Belgium, Finland and Spain made it even easier to file and pay taxes electronically. The Czech Republic mandated electronic filing for all taxes, reducing compliance time by (317) hours. Electronic systems are increasingly used in the world. In Belarus the online tax portal has become fully operational for use by all taxpayers, and in Macedonia electronic filing is now mandatory for all taxes. In Latin America and the Caribbean most major reforms enhanced electronic systems. This is a welcome development, since the region's businesses spend the greatest average time on tax payment and filings. Aside from Mexico's reforms, Peru made it easier to pay value added tax by providing taxpayers with free software. Colombia's tax authority upgraded its electronic payment system to allow electronic filing and payment of corporate income tax and value added tax. Guatemala introduced regulations mandating use of electronic systems for tax payments and filings, reducing the number of payments.

In Lebanon taxpayers can make electronic payments at any post office. In Tunisia the government initially introduced an intermediate option allowing online filers to print a receipt number and make their payment in any tax office. The past year's reform consolidated electronic payment and filing through the declaration online system.

Faster refunds and processing times for online transactions are key incentives to encourage use of new technology. Australia, Ireland, Taiwan (China), the United Kingdom and the United States offer inducements such as these. South Africa 
waived late penalties for online filers in 2007. France introduced tax credits for individual taxpayers filing their returns electronically, though in the future this will apply only to first time electronic filers (World Bank, Doing Business Report, 2010).

Egypt issued a decree by Law No. 201 of 2014 on 16 December 2014, adding a second paragraph to article No. 103 of the Income Tax Law No. 91 of 2005. The new Law prescribed that "The tax due on corporations (Egyptian joint stock companies, companies limited by shares and limited liability companies) as well as the tax due on public jurisdiction persons should be paid electronically". The decree will be effective from the financial year 2014/2015, for corporate entities and will operate as described below.

According to completing the tax returns, the authorized signatory for the corporate entity should sign a bank deposit form at a designated bank and effect transfer of any tax due to the Egyptian Tax Authority's account (ETA). The designated bank will issue a receipt as proof of transfer of funds to the (ETA) account. The bank receipt must be submitted together with the tax returns for (ETA) verification and stamping of the tax return as received (Ahmed, 2014).

Second lesson: Combine and consolidate taxes: Having more types of taxes requires more interaction between businesses and tax agencies. Businesses complain that a higher number of taxes is cumbersome. The problem is greatest in poor countries, which rely more on 'other taxes' rather than income tax and VAT. In Tanzania, for example, local authorities impose (50) business taxes and fees. But the number of taxes is a burden in some rich countries too. In New York City income taxes are levied at the municipal, state and federal levels. Each is calculated on a different tax base, so businesses must keep three sets of books. Such an approach costs governments more in collection costs as well.

Almost (50\%) of countries have more than one labor tax or contribution, $(27 \%)$ more than one tax on profits, and $(41 \%)$ more than one tax on property. If the base is the same (salaries, profits or property), why not just combine these? Having multiple taxes increases the bureaucratic burden for both the taxpayer and the tax administration. So combining or consolidating taxes is also a worthwhile reform.

For example, most countries have more than one labour tax, yet such taxes are typically based on gross salaries. Why not unify them? Tax offices can then distribute the revenues among government agencies. Slovakia did just that: its single social contribution tax funds, health insurance, sickness insurance, old age pensions, disability insurance, unemployment benefits, injury insurance, guarantee insurance and reserve fund contributions. In many countries social security agencies would be reluctant to part with their powers, especially if there is a chance that tax offices won't give them their share of revenues. To gain their trust, an automatic separation of revenues can be introduced so that there is no room for discretion.

The primary taxes are income tax, VAT, import duty, export tax, excise duty and special excise, provincial turnover tax and property tax. There are taxes at different levels of government. There is also the social responsibility levy, debits tax, share transaction levy, economic service charge, financial transactions tax and various stamp duties. And there is a whole host of industry specific taxes. It is way too complicated.

Reformers can look to Georgia, which in 2004 cut the number of taxes from 21 to nine. Businesses have praised the new, simpler system. In 2001 Russia consolidated several business taxes, cutting the number of taxes from (20) to (15). And Iran recently merged (3) taxes into (1) to ease payment. Improvements were also made in Senegal. Small businesses can now pay one tax that has a lower rate and consolidates four previous taxes. In addition, several exemptions were abolished to widen the tax base.

Some taxes can be dropped altogether. Reforms should target minor excises and stamp duties, which cost money to administer but do not raise much revenue. An example is a turnover tax, which is levied on a firm's inputs and again on its outputs, so tax is paid on tax. The main alternative to a turnover tax - a VAT - levies tax only on the difference between inputs and outputs, avoiding double taxation.

Another alternative, a sales tax, does the same by taxing only outputs, as in the United States. Mozambique abolished its turnover tax in 1999, replacing it with a VAT. Georgia eliminated its turnover tax, which was levied on top of a VAT, as a part of its 2004 reform. But another (44) countries maintain a turnover tax, including Argentina, Belarus and Tunisia. Almost all have a VAT or sales tax as well. In 2005, Uzbekistan introduced a (1\%) tax on turnover, which outweighed reductions in corporate and labour taxes.

Small businesses have a particularly hard time dealing with multiple tax payments. Why not help them by making their interactions with the tax agency simpler? This is what Brazil did. In 2001 it introduced the Simples system, which allows for one monthly tax payment for businesses with annual revenues below $\$ 1.1$ million. The payment covers eight taxes, including four federal and state 
consumption taxes, two profit taxes, one labour tax and one municipal tax (Caralee and Rita, 2007).

Poland has the highest administrative costs of tax collection among OECD countries, at $(2.62 \%)$ of revenue. The reason? A business has to make (41) tax payments a year, including (4) different labor taxes. Many countries in Eastern Europe and Central Asia have a similar burden. In contrast, tax administration in Sweden costs only $(0.59 \%)$ of revenue, since all business taxes can be paid online. Several countries have joint tax payments. Bosnia and Herzegovina combines (3) labor contributions and Uruguay (4) in one monthly payment. In Portugal companies can pay (2) taxes on profits together.

\section{Third lesson: Simplify tax administration:}

A simpler tax system lowers the opportunity for corruption in the tax system. The question arises, how does one define "tax simplicity", particularly in a way that would allow comparisons on an international level? The only viable option available is to use the doing business reports produced by the World Bank Group. The doing business reports measure the ease of doing business as reflected in (10) indicators, including one on complying with the tax system: (paying taxes). Two sub indicators of the paying taxes indicator are: time to comply and number of payments. The premise is that the lower the time taken to comply with the tax system and the fewer the number of payments, the easier it is for businesses to comply with their tax paying obligations.

The TAXTIME indicator measures the time it takes to prepare and file tax returns for the three major taxes that impact an average medium-sized business, and the time taken to make the payments of these taxes. The preparation time includes the time taken to collect all information and data needed to calculate the tax liability and to fill out the declaration forms. If the tax regime has complex provisions which impose requirements to provide information that may not be available to a business in the normal course of carrying on its business, this adds to the time taken to comply.

Finally, the time taken to actually complete declaration forms is also included, and so is the time taken to make the payments. If the declaration forms are complex that would result in a higher time to comply. And if payment procedures are inconvenient, time to comply increases. All of these raise compliance costs for taxpayers. This provides businesses with the incentives to accede to rent-seeking tax officials who may be able to help cut down on the time and cost of tax filing and payments in return for an appropriate rent. This represents one link between tax complexity and tax corruption.
Similarly, TAXPAY indicator is a good measure of the ease of payment procedures of taxes. In inefficient tax administrations, taxpayers often face onerous payment procedures, have limited options in terms of where the payments can be made, and may have to stand in long lines to submit their tax payments. The DB methodology captures all this, and in addition, it factors in the benefits of electronic filing and payments.

Therefore, it implicitly assumes that e-filing and epayment systems significantly reduce compliance burdens. Electronic tax systems thus get a disproportionately high weight, and rightly so. It is seen around the world that successfully operating E-Systems have been extremely useful to tax administrations in reducing tax compliance time and cost for tax payers and direct contact between taxpayers and tax officials. So, the doing business's paying taxes sub-indicator is also useful in judging a tax system's simplicity. Based on this reasoning, the two sub-indicators are chosen as working definitions of tax simplicity (Rajul and Nihal, 2015).

Many tax reforms are aimed at simplifying the tax law and making it easier for firms to comply with regulations. A bold step in this direction involves eliminating tax exemptions, tax holidays and other special treatment for different types of businesses, to achieve equal treatment for all businesses. Eliminating tax exemptions can be difficult, because they are often used as tax incentives with specific objectives. Reform experiences in such economies as Georgia, Mauritius and Turkey show that it takes political will and buy-in from stakeholders to succeed.

In 2005 Egypt eliminated all tax exemptions and introduced a flat tax of $(20 \%)$ on corporate income and became $(22.5 \%)$ accordance to the law 96 of 2015. Mauritius shifted from a tiered rate to a single rate with a broader tax base. Georgia's tax reform of 2008 was multifaceted. It lowered the corporate tax rate, abolished the social tax and introduced online filing, reducing the number of tax payments and the tax burden. Easier compliance also made enforcement less burdensome. Surveys of businesses showed that the average number of visits with tax officials fell from (8) in 2005 to only (0.4) in 2008 (World Bank, Doing Business Report, 2010).

More than half of countries require special accounting books for tax purposes. Two-fifths have more than one law per type of tax. So businesses spend a lot of time complying with tax regulations. Making the tax rules for businesses complex is unlikely to bring more revenue quite the opposite. Countries that don't require special books have $(10 \%)$ more revenue (as a percentage of GDP) on 
average than countries that do. And having a clear tax law increases tax revenue by $(6 \%)$ on average. Clarity on audit rules can make a big difference. While the vast majority of countries have a system of self-assessment for calculating taxes, only about $(16 \%)$ use risk analysis as the basis for their tax audits. Yet tax audits are a big opportunity for bribes. Using clear rules to determine who and how to audit can reduce this opportunity and increase tax revenue. Indeed, countries with audits based on risk analysis have higher tax revenue as a percentage of GDP (18\%) higher on average despite having lower tax rates. The reason is that businesses have fewer incentives to hide revenues (Eelco and Katarzyna, 2014).

Fourth lesson: Reduce tax rates and broaden tax base: Governments impose taxes to finance public services. But taxes must first be collected and high tax rates do not always lead to high tax revenues. Between 1982 and 1999 the average corporate income tax rate worldwide fell from (46\%) to $(33 \%)$, while corporate income tax collection rose from $(2.1 \%)$ to $(2.4 \%)$ of national income. This outcome was achieved because more businesses entered the formal economy and because tax exemptions and other tax incentives were reduced or eliminated.

Poorer countries try to levy the highest amount of tax on businesses. Some claim that these high taxes are needed to fund public services and correct fiscal deficits. The evidence suggests otherwise. Higher rates typically do not lead to higher revenues in poor countries. Instead they push businesses into the informal economy. As a result the tax base shrinks and less revenue is collected. Reducing tax rates has been a trend in other Eastern European and Central Asian countries. Most reformers Armenia, Bulgaria, Estonia, Kazakhstan, and Slovakia have seen tax revenues rise. The larger the share of informal business activity before reform, the higher the revenue growth after.

More recent reformers have shown similar results. Ghana exceeded its mid-year revenue targets despite significant cuts in corporate tax rates in the last two years. Albania's corporate tax revenue rose $(21 \%)$ after the rate was cut, while in Moldova it jumped (28\%). In Romania, budget revenues grew $(8 \%)$ in real terms in the first quarter of 2005 relative to the same period in 2004, despite the new flat tax. Economic growth in these countries is a factor in the increased revenues. But compliance is also up.

High tax rates can force companies into the informal sector. In the Democratic Republic of Congo, with taxes as high as twice the commercial profit for a company with a profit margin of (20\%), businesses have a strong incentive to evade taxes.
Such countries can increase tax revenue by lowering rates and persuading more businesses to comply with the new tax system. Even countries with a smaller informal sector can gain from this strategy. Greece saw its corporate tax revenue grow from $(4 \%)$ of GDP to $(5 \%)$ after reducing the corporate tax rate in 2005 . The size of the tax burden on businesses from an important matters for investment and growth, where taxes are high and corresponding gains seem low. A recent study shows that higher tax rates are associated with lower private investment and fewer formal businesses. In any case, a better way to meet revenue targets is to encourage tax compliance by keeping rates moderate. Russia's large tax cuts in 2001 did exactly that. Corporate tax rates fell from $(35 \%)$ to $(24 \%)$, and a simplified tax scheme lowered rates for small business. Yet tax revenue increased by an annual average of (14\%) over the next three years. One study showed that the new revenue was due to increased compliance.

Lower rates work best when their administration is simple. They are undermined by exemptions that shrink the tax base. Tax revenue has fallen in Uzbekistan, where the enthusiasm for income tax cuts was not matched by efforts to improve tax administration and expand the tax base (Caralee and Rita, 2007).

This is what happened in Egypt, exactly, has been reduced corporate tax rate by Law 91 of 2005 by Rate reduction $(41.2 \%)$. It did not accompany the tax cuts caused by the above-mentioned law, broaden tax base by sufficient way, which is evident from the table (2), where the proportion of the total taxpayers for the total population from $(6.75 \%)$ in 2006 to $(8.32 \%)$ in 2012 .

Where it was clear us from table (2), that the increasing of total taxpayers with a total population, by convergent ratios, where the population was (72000000), the number of taxpayers (4866419), equal (6.75\%) in 2006. While the population was (76100000), total taxpayers (5918744), equal $(7.77 \%)$, in the year 2009 . When the population reached (82.336000) million, total taxpayers $(6,852,549)$, equal $(8.32 \%)$ in the year 2012. And therefore, it did not result in the abovementioned law, sufficient increasing to the tax base.

\section{Conclusion:}

it is time for a new era of tax reform in Egypt, but the success of government in carrying this through will depend on their ability to address the four key challenges highlighted earlier:

- supporting losers as well as rewarding winners from reform;

- avoiding the temptation to put off change for tax system; 
Table (1) The proposals for a good tax system in Egypt

\begin{tabular}{|c|c|}
\hline The proposal & The explanation \\
\hline $\begin{array}{l}\text { clear objectives for the } \\
\text { tax system }\end{array}$ & $\begin{array}{l}\text { 1- The tax system is designed to raise revenue to fund public expenditure. } \\
\text { 2- It aims to balance a country's budget, probably over a period. } \\
\text { 3- It considers social objectives such as issues of redistribution. } \\
\text { 4- It has regard to the ability to pay tax is progressive. }\end{array}$ \\
\hline $\begin{array}{l}\text { a strategy plan for the } \\
\text { tax system }\end{array}$ & $\begin{array}{l}\text { 5- The tax system is stable and consistent, to ensure that long term investment decisions } \\
\text { can be taken, confident in the knowledge that the tax rules will not change significantly } \\
\text { the commercial validity of those decisions. } \\
\text { 6- It works to take a fair proportion of the value of the country's natural resources in tax } \\
\text { revenues, whilst allowing those operating in such areas the opportunity to achieve a fair } \\
\text { reward for their efforts. } \\
\text { 7- It helps, rather than hinders, business and trade. If the country wishes to trade } \\
\text { internationally, the tax system must be competitive and have regard to how systems in } \\
\text { other economies operate. } \\
\text { 8- It is flexible and responsive to economic and social change within a country. To have } \\
\text { the potential not just to raise revenues, but also to encourage changes in behavior which } \\
\text { society is agreed upon. }\end{array}$ \\
\hline $\begin{array}{l}\text { The tax system has } \\
\text { efficient and coherent }\end{array}$ & $\begin{array}{l}\text { 9- The tax system has mechanisms in place to allow for proper prior consultation with } \\
\text { relevant stakeholders, Consultation may help drafting and implement legislation which } \\
\text { achieves stated objectives. } \\
\text { 10-It is understandable, clear, and easily accessible. } \\
11 \text { - It ensures the interaction between taxes is fully considered and operates sensibly. } \\
\text { This consideration should extend to multinational interactions if the country has } \\
\text { international links of importance. } \\
\text { 12- It minimizes the administrative burden on both taxpayers and government for the } \\
\text { preparation, filing, and payment of taxes. Online filing and the consolidation of the } \\
\text { number of taxes may assist. }\end{array}$ \\
\hline $\begin{array}{ll}\text { The tax system } & \text { has } \\
\text { equitable } & \text { and } \\
\text { transparency } & \end{array}$ & $\begin{array}{l}\text { 13- The tax rules should be in legislation that is accessible to users, rather than being } \\
\text { dependent on the practice of the tax authorities. } \\
\text { 14- The tax system should be enforced in a consistent manner by the tax authorities. } \\
\text { 15- There should be a clear route for resolving a dispute between taxpayers and the tax } \\
\text { authorities, during a sensible timescale. } \\
\text { 16- Domestic tax legislation should be consistent with wider law both international and } \\
\text { non-tax. } \\
\text { 17- The system operates on a basis of mutual trust and transparent, taxpayers are } \\
\text { assumed to be honest unless proved otherwise in their dealings with the tax authorities. }\end{array}$ \\
\hline $\begin{array}{l}\text { The relation between } \\
\text { Egyptian tax authority } \\
\text { and taxpayers }\end{array}$ & $\begin{array}{l}\text { 18- There needs to be a recognition that tax authorities should help taxpayers to achieve } \\
\text { their tax compliance. } \\
\text { 19- Tax authorities and business should promote a constructive dialogue and move } \\
\text { away from adversarial relationships. } \\
\text { 20- There needs to be recognition of the role of tax advisers as an important part of the } \\
\text { smooth running of the tax system. }\end{array}$ \\
\hline
\end{tabular}

Source: preparation by the researcher accordance to paying taxes report 2009, World Bank, p.p. 64-66. 
Table (2) The percentage for the number of taxpayers to the number of population 2006/2012

\begin{tabular}{|l|l|l|l|l|l|l|l|}
\hline Years & $\mathbf{2 0 0 6}$ & $\mathbf{2 0 0 7}$ & $\mathbf{2 0 0 8}$ & $\mathbf{2 0 0 9}$ & $\mathbf{2 0 1 0}$ & $\mathbf{2 0 1 1}$ & $\mathbf{2 0 1 2}$ \\
\hline Total taxpayers & $\mathbf{4 8 6 6 4 1 9}$ & $\mathbf{5 2 2 3 1 9 1}$ & $\mathbf{5 5 6 9 5 6 7}$ & $\mathbf{5 9 1 8 7 4 4}$ & $\mathbf{6 2 6 3 2 6 2}$ & $\mathbf{6 5 6 4 7 5 2}$ & $\mathbf{6 8 5 2 5 4 9}$ \\
\hline Total population & $\mathbf{7 2 0 0 0 0 0 0}$ & $\mathbf{7 3 0 0 0 0 0 0}$ & $\mathbf{7 4 0 0 0 0 0 0}$ & $\mathbf{7 6 1 0 0 0 0 0}$ & $\mathbf{7 8 5 0 0 0 0 0}$ & $\mathbf{8 1 4 0 0 0 0 0}$ & $\mathbf{8 2 3 3 6 0 0 0}$ \\
\hline percentage & $\mathbf{6 , 7 5}$ & $\mathbf{7 , 1 5}$ & $\mathbf{7 , 5 2}$ & $\mathbf{7 , 7 7}$ & $\mathbf{7 , 9 7}$ & $\mathbf{8 , 0 8}$ & $\mathbf{8 , 3 2}$ \\
\hline
\end{tabular}

Source: prepared by the researcher, according to data obtained from the General collection administration, Egyptian tax authority, and the website of the free encyclopedia "ar.wikipedia.org."

\section{References}

1. Andrew Sentence: Paying Taxes Report, 2015, World Bank Group, www.PWC/payingtaxes.

2. Ahmed El-Sayed: requires corporate income tax payments to be made electronically, 2014, Ernst \& Young (Egypt), Global Tax Alert, www.ey.com.

3. -Advanced Medical Technology association: AdvaMed's Tax Reform Principles, without year, Washington, USA.

4. Bank Information Center (BIC): without author, International Financial Institutions and Egypt, 2007.

5. Chaire Kumar: tax and development, 2014, Transparency Initiative, www.transparencyinitiative.org.

6. Caralee McLiesh and Rita Ramalho: How to reform the options for reform? 2007, Doing Business Report, World Bank Group.

7. Caralee McLiesh and Rita Ramalho: Why reform tax systems? 2009, doing Business Report, World Bank group.

8. Doing Business Report, without author, 2010, The International Bank for Reconstruction and Development/ The World Bank, www.worldbank.org.

9. Doing Business report 2015, without author, World Bank group, The International Bank for Reconstruction and Development, www.worldbank.org.

10. Eelco van der Enden and Katarzyna Bronzewska: the Concept of Cooperative Compliance, September 2014, published in the Bulletin for International Taxation, Vol. 68, and Paying Taxes Report 2015.

11. Jorge Martinez-Vazquez and Richard M. Bird: Sustainable development requires a good tax system, 2015.
12. Jorge Martinez-Vazquez, Mark Rider and Sally Wallace, Tax Reform in Russia, 2007, published by Edward Elgar publishing, Inc. William Pratt House 9 Dewey court Northampton Massachusetts 01060 USA.

13. Paying Taxes report, without author, 2009, World Bank group.

14. Paying Taxes report, without author, 2011, World Bank group.

15. ROBIN BURGESS and NICHOLAS STERN, Taxation and Development, June 1993, Journal of Economic Literature Vol. XXXI.

16. Rajul Awasthi and Nihal Bayraktar, Can tax simplification help lower tax corruption? 2015 Eurasian Economic Review.

17. ROY BAHL: TAXATION AND ECONOMIC DEVELOPMENT, A Blueprint for Tax Reform in Ohio, 1996, Battelle press 505 King avenue Columbus, Ohio.

18. Roy Bahl and Sally Wallace: Tax Reform and economic development the Jamaican case, 2007, national library of Jamaica cataloguing in publication data.

19. The World Bank, Middle East and North Africa Vice Presidency, Public Financial Management Reform in the Middle East and North Africa: An Overview of Regional Experience, Report No. 55061-MNA, Part I Overview and Summary June 2010. 